\title{
Preface to the 1967 Edition
}

This, essay was written in 1949-1950 and published in 1952 in the Princeton compendium, Socialism and American Life, edited by Donald Egbert and Stow Persons. Since then about a half-dozen published studies on American socialism have appeared (as well as a dozen unpublished Ph.D. theses), and on American communism ten scholarly volumes have been published in the series edited by Clinton Rossiter for the Fund for the Republic, while a score of other books, historical, analytical, and sensational (see the Bibliographical Essay, pp. 194-201), have increased the bulk of writing on this subject.

This essay is being reprinted unchanged, and the reasons for this are twofold. First, despite the number of books on the Marxian movements in the United States, there is still not a single volume which encompasses, as this sketch does, the history of all the Marxian parties-the Socialist Labor Party, the Socialist Party, the Communist Party-as well as the various splinter and sectarian groups and personalities; and while many details have been added by the more specialized studies, the historical outline as presented in this monograph remains untouched. Second, and perhaps more important, the theoretical and interpretative framework presented in this essay has influenced many of the subsequent studies in the field, and this may be its enduring contribution.

The basic question confronting all the students of American Marxism is the one posed in 1906 by Werner Sombart: "Why is there no socialism in the United States?" In the most advanced capitalist country of the world, there has been no Labor Party, little corporate class consciousness, and feeble intellectual leadership from the Left-though clearly the ideas of Marxism and the political proposals of the American Socialist Party are now the common coin of American intellectual life and its polity.

Most of the explanations-one thinks here of those given two generations ago by Sombart or by Selig Perlman, or of the analyses made by such contemporary theorists as Sidney Hook, Louis Hartz, or S. M. Lipset-have stressed the distinctive conditions of American life, which made a barren ground for a socialist movement: the idea of equality, the opportunities for social mobility, the commitment to liberalism, the constraints of a two-party structure, the rising standard of living, the opportunity for labor to realize its demands through economic bargaining, and the like.

The one question which all such explanations eschewed, and the one this essay attempted to answer was: Why did the socialist movement, as an organized political body, fail to adapt to the distinctive conditions of American life and find a place in the society as did, say, the British Labour Party in England (though not the Social Democratic Federation, 
organized by M. H. Hyndman, which was the first socialist political organization in Great Britain)? The answer explored in this essay-and it is stated baldly in this Preface though the documentation in these pages relates specific times and circumstances-is that a set of ideological blinders prevented the American Socialist Party from understanding the society. To state the paradox most forcefully: the American Socialist Party, though often called reformist or right-wing, was actually too much a Marxist party.

In the language of the Left, reformist or right-wing derives from an attitude towards revolution or the use of force in inducing social change. Yet reformist parties may also be Marxist in that their basic categories for interpreting a society are drawn from a specific canon, and their judgments about the class or social structure are made in Marxist terms; and thus they are sectarian in their own way. What was true about the American Socialist Party was equally true, I would argue, about the German Social Democratic Party or the French Socialist Party, but in a different context. Though also reformist or right-wing, they were equally Marxist; and though they were able to organize large sections of the working class in their countries, at crucial moments their ability to act, or adapt, was paralyzed because of ideological rigidity.

To cite a crucial illustration: In 1930, a Social Democratic government under Herman Müller ruled in Germany; yet when the Socialists were confronted with the deep economic depression and widespread unemployment, they did not know what to do. For them, as Marxists, there was no way of "tinkering" with the capitalist system. As one of the socialist theorists, Fritz Napthali, put it: "The depression simply had to run its course." In fact, the Socialist government followed orthodox deflationary policies, cutting spending and balancing budgets, thus extending the unemployment and deepening the crisis. In retrospect, it seems astonishing that the socialist economists, among them such gifted men as Rudolf Hilferding-whose work Finanzkapital served as the basis of the Marxian theory of imperialism, and who served as finance minister in the Müller cabinet-should have been so shortsighted. Yet Marx and Engels had taught that economic crises were endemic in the capitalist system, that imbalances were introduced in the society by chronic "overproduction," and that the system could "start up" again only when. such "overproduction" was used up. The thought that unorthodox fiscal policy could tap idle savings or that the state could intervene to redress economic balances-measures introduced by Wigforss in Sweden and Schacht in Germany, and ideas associated with John Maynard Keynes in England-was alien to the Marxist economists.

In the United States, to take a different illustration, the American Socialist Party during the 1930's moved left at a time when the entire 
labor movement was swinging behind Franklin D. Roosevelt and the New Deal, because of the socialists' ideological judgment that Fascism would necessarily come to the United States and it was necessary to prerare for "revolutionary" activity. Fascism, from this point of view, was the "last stage of monopoly capitalism," and the American capitalist class, like its European brethren, would shed the mask of bourgeois democracy in order to enforce naked repression against the working class. Apart from the misreading of the character of fascism, such ideas as cultural diversity, or the role of value systems in influencing political behavior, were alien to Marxist thought. From the mechanical Marxist point of view, the important source of social change and the root of power are in the economic "substructure" of society, and all politics flow from that source. "Yet England went through as severe an economic crisis as Germany, and barely fumbled its way through to recovery, yet no largescale fascist movement took root in England because of its distinctive ethos of liberty and its particular structure of civil, not ideological, politics.

At one crucial turning point after another, when the socialist movement could have entered more directly into American life-as did so many individual socialists who played a formative role in liberal political development-it was prevented from doing so by its ideological dogmatism. Why and how this came about is the burden of a large part of this essay.

This historical thesis is rooted in a broader sociological framework which seeks to explain the diverse character of radical social movements, and their particular dilemmas of social action, in a society they seek to change by divers means. The organizing metaphor I used was Martin Luther's phrase describing the character of his church: it was, he said, "in the world, but not of it"; it lived in the society, but transcended it by making a judgment outside of it. I chose the religious metaphor quite deliberately, because the radical movements as secular religions, both as sects and churches, have faced problems similar to the earlier religious movements in confronting an alien world. I felt, too, that the particular tensions of the secular radical movements could be explained by the threefold paradigm implicit in the metaphor itself.

\footnotetext{
'Thus, in the 1920's, Trotsky held that England and America might go to war with each other since they were the victorious economic powers of World War I, and their ensuing and necessary rivalry for the markets of the world inevitably would lead to a clash. (See Whither England [International Publishers, 1925].) As late as 1948, in his book The American Democracy, Harold Laski argued that fascism would arise in the United States as an inevitable concomitant to capitalism. Such a belief, it should be pointed out, was nourished by Jack London's indigenous and influential novel the fanciful The Iron Heel, which predicted the naked and outright repression of the working class by an organized capitalist class using mercenaries.
} 
The Socialist Party, as I saw it, was "in the world, but not of it." It was in the world, in that it proposed specific reforms of society and was melioristic in its immediate aims; but it was not of society, in that it refused to accept responsibility for the actions of the government itself. Thus, to maintain its purity, the Socialist Party straight-facedly-sixty years ago-expelled a retired Civil War veteran for accepting a minor position in a "capitalist" municipal administration (see the discussion of the Gridley affair, pages 85-86); or, more seriously, during the Spanish Civil War it disapproved of government aid to the Loyalists because it sought only "workers' aid," not "capitalist aid." A religious movement can maintain its divided stance because it is not called upon to prove its ultimate judgment about the nature of God's grace; this is simply a matter of faith. But a secular movement, living in time, cannot escape the liabilities of its political judgments, and when it is rendered politically ineffectual by its contradictory attitude, faith eventually wanes in the light of experience.

The Communist Party, within the metaphor, lived neither in the world nor of it, but sought to encapsulate itself as a world of its own. It thus faced a peculiar problem of cohesion. Other, earlier alien movements, such as the utopianism or anarchism, had also rejected existing society completely. But the utopians retreated to an Icarian wilderness which was spatially apart from the world, while the anarchists psychologically suspended time while waiting for the magical "deed" that would instantly transform the world. The Communists, living in the society while seeking to promote a revolutionary movement, sought to maintain their zeal by establishing a psychological distance from the society (by nurturing a wholesale distrust of all institutions as "bourgeois" institutions) and by instilling a combat posture in their adherents. But it was that very distance, and the sense of strangeness it created, which allowed individuals to magnify the fear of Communists and make them such ready targets of hostility during the Korean war and the McCarthyite excesses in American life.

The American labor movement, to complete the logic of the metaphor, learned to live in and of the world, and in so doing managed to transform some of the values of the society-most notably in winning the acceptance of collective rights and group action as legitimate norms, as against the older tradition of individualism.

While a full-scale history of American radicalism and a comprehensive sociology of social movements would necessarily add many other elements, fifteen years later I still stand by this organizing metaphor as a useful explanatory model.

Fifteen years later, a New Left has appeared in the United States. This is not the place for an extended analysis of this phenomenon, yet I 
feel that the scheme used to understand the radical movements of the first half of the century has its analytical utility here as well.

What is striking about the New Left-and I deal here only with its most interesting grouping, namely the Students for a Democratic Society, circa 1962-1965-is its dilemma of being in but not of the world, in part, for the very reason that placed someone like Norman Thomas in the same position: namely, that its critique of the society (apart from the Vietnam War, which has given a special edge of bitterness to its feelings) is primarily moral, not political. The themes of the New Left are those of alienation and dehumanization. It rejects materialism and competitiveness, and it is horrified by the bureaucratic and hierarchical character of organization. While its manifest focus is on American society, and its rhetoric is directed against "capitalism," the heart of the critique is actually against "industrial society"; and what is so striking in this regard is the similar critiques, in more veiled and abstract philosophical terms, by young "Marxists" in Poland and Yugoslavia against their communist regimes which are also industrial societies organized around the norms of "efficiency" and "production."

What is lacking in the American New Left is any precision of analysis (therefore its reliance on such vague terms as Power Structure, the Establishment, or simply "the system") or any discussion of political philosophy. Some of this lack derives from the emphasis on "gut feeling" and emotion (and a consequent strong anti-intellectualism); some from the inability to locate the sources of power and change in a society where three or more criteria (property, technical skill, and political mobilization) have become the bases of class and social mobility. Their politics thus becomes, on its negative side, simply one of protest or of "confrontation," by which they mean the tearing down of all authority. And to the extent there is a positive proposal, it is an inchoate, primitive Rousseauism, which preaches the virtue of participatory or direct democracy, since in a bureaucratic society "people are unable to control the decisions which affect their lives." (The idea that if individuals could make such decisions they would be progressive ones is an old Populist fallacy. On the theory of participatory democracy, should individuals in a neighborhood have the right to exclude colored people, or those in a work group to refuse a job to a Negro, because such presences would disrupt the existing character of the neighborhood or work group? Few members of the New Left have ever thought through the conflicting nature of group rights or the problems inherent in the tensions between liberty and democracy.)

Whatever one thinks of the criticisms of contemporary society by the New Left-and one can share the apprehensions about bureaucracy while at the same time appreciating the openness of American institutions 
and their receptiveness to change-the crucial problem is how one translates these concerns into political terms and how one confronts, in this regard, the dilemmas of politics and ethics: politics has the virtue of compromise and responsibility, while moralizing has the implicit vicesince it posits a theory of exclusive truth-of total solutions and elimination of dissent as error or falsehood; politics, though, has the vice of opportunism, while moral views have a foundation in conscience. How, then, does one act politically in a moral way, and act morally in politics?

The New Left tends to feel that all such problems-to the extent they perceive them-are being confronted for the first time. And it is at this point that the history of the different Marxian movements-the opportunism of the socialists and the totalitarianism of the Bolsheviks-have relevance for the present. For the New Leftists are in a difficult position: like sons without fathers, they are nihilists without memory. Coming "out of themselves," with no sense of a past, they have a callow vitality, drive, and hubris, uncomplicated by notions of history, complexity, tragedy, or doubt. And yet, though they reject the radicals of the 1930's, the New Leftists are like them in an uncanny way. The radicals of the 1930's also had no "middle generation" between themselves and the pre-World War I radical movement. And, secure in their belief that they were on the express train of History, they were equally heedless of the few small voices that warned them of the wreckages of the past and of those that might lie ahead. (When told of Kronstadt, the episode in 1921 when Lenin and Trotsky shot down the revolutionary Red sailors because they were demanding free elections; the young communists of the Thirties would say, jeeringly, "Who cares about old history?")

While it is too facile to say that a generation which does not know its own past is bound to repeat those errors, it is possible that a generation which knows its past is more likely to make more intelligent decisions about its future. And that is the virtue of History.

For those who have lived through the radical past, T. S. Eliot's elegy in the Four Quartets can serve as its epitaph:

We cannot revive old factions

We cannot restore old politics

Or follow an antique drum.

These men, and those who opposed them,

And those whom they opposed

Accept the constitution of silence

And are folded in a single party.

Whatever we inherit from the fortunate

We have taken from the defeated. 
What they had to leave us-a symbol:

A symbol perfected in death. ${ }^{*}$

But an epitaph is not a forgetting; it is a requiem whose echoes can unlock the past: "This is the use of memory / For liberation-not less of love but expanding. ..."

\section{Daniel Bell}

\section{Columbia University}

* Excerpt from “Little Gidding" in Four Quartets, copyright 1943 by T.S. Eliot and renewed 1971 by Esme Valerie Eliot, reprinted by permission of Harcourt Brace \& Company. 
